\title{
Cladistic analysis of Abracrini genera (Orthoptera, Acrididae, Ommatolampinae)
}

\author{
MARIA KÁTIA MATIOTTI DA COSTA ${ }^{1,3}$; GERVÁSIO SILVA CARVALHO ${ }^{2,5}$ \& CARMEM SILVIA \\ FONTANETTI ${ }^{1,4}$ \\ ${ }^{1}$ Universidade Estadual Paulista "Júlio de Mesquita Filho" - Instituto de Biociências- Departamento de Biologia, Campus de Rio \\ Claro - Av. 24A, 1515- Bela Vista - São Paulo/SP - CEP: 13506-900, São Paulo, SP, Brasil. E-mail. ${ }^{3}$ katiamatiotti@yahoo.com.br; \\ ${ }^{4}$ fontanet@rc.unesp.br \\ ${ }^{2}$ Pontifícia Universidade Católica do Rio Grande do Sul - Faculdade de Biociências - Departamento de Biodiversidade e Ecologia - \\ Laboratório de Entomologia. Av. Ipiranga, 6681 - Partenon -Porto Alegre/RS - CEP: 90619-900, Porto Alegre, RS, Brasil. E-mail: \\ ${ }^{5}$ gervasio@pucrs.br
}

\begin{abstract}
A cladistic analysis using 50 characters and 21 genera of the Neotropical tribe Abracrini was performed in order to test the monophyly of the tribe and to reconstruct a phylogenetic hypothesis. Abracrini is supported by three synapomorphies: penultimate article of maxillary palps unflattened; second segment of hind tarsi short and internal apophysis of cerci vestigial. The analysis demonstrates that Abracrini is a monophyletic tribe, as well as a relationship among its genera was (Psiloscirtus splendidus (((Parasitalces sexnotata + Sitalces volxemi) (Arimacris trinitatis (Caruaruacris bivittatus + Salvadoracris nigritus $)))((($ Eusitalces vittatus + Liebermannacris dorsualis $)$ (Monneacris fascipes (Robustusacris balzapambae (Xiphiola borellii (Eujivarus fusiformis + Roppacris griseipes))))) (((Omalotettix obliquus + Orthoscapheus coryaceus) (Abracris dilecta + Jodacris ferruginea)) (Teinophaus saussurei (Rhachicreagra nothra (Agesander ruficornis + Ixalotettix compactus))))))). Further data on biogeography and a distribution map are provided.
\end{abstract}

Key words: grasshoppers, phylogeny, Neotropical region, taxonomy, distribution

\section{Introduction}

Ommatolampinae includes six tribes, with 285 species distributed throughout 111 genera (Eades \& Otte, 2009). Its members can be distinguished from the remaining acridids on the basis of the shape of mesonotum, which is either not externally visible or only visible at the posterior region.

In South America there are various genera, which occur on a wide range of regions and vegetation, from middle tree-top extracts to bushes and young trees in clearings, as well as on small secondary anthropogenic formations.

Amédégnato (1974) proposed the classification of Neotropical acridoids, adding several subfamilies to Acrididae. Abracrini was included in Ommatolampinae, which was among the mentioned subfamilies.

Abracrini is composed of 21 genera with 78 species (Eades \& Otte, 2009). The tribe is distributed throughout the Neotropical region, having been recorded in Mexico, Honduras, Costa Rica, Panama, Colombia, Venezuela, Trinidad and Tobago, French Guiana, Ecuador, Brazil, Peru, Bolivia, Paraguay and Argentina. Abracrini genera are notably heterogeneous in terms of their internal and external morphology, but within the genera the species follow a more uniform pattern. This heterogeneous morphological characteristic probably results from its widespread geographical distribution.

The genera within this tribe can be basically differentiated through male genitalia characters. They are generally small sized grasshoppers, tending towards macropterism, micropterism or apterism. 